\title{
Effects of Biochar on the Abundance of Three Agriculturally Important Soil Bacteria
}

\author{
Tazeen Fatima Khan', Monzur Morshed Ahmed ${ }^{2}$, Shah Muhammad Imamul Huq ${ }^{*}$ \\ ${ }^{1}$ Bangladesh-Australia Centre for Environmental Research (BACER-DU), Department of Soil, Water and \\ Environment, University of Dhaka, Dhaka, Bangladesh \\ ${ }^{2}$ Industrial Microbiology Laboratory, Institute of Food Science and Technology (IFST), Bangladesh Council of \\ Scientific and Industrial Research, Dhaka, Bangladesh \\ Email: *imamhuq@hotmail.com
}

Received 13 January 2014; revised 17 February 2014; accepted 27 February 2014

Copyright (C) 2014 by authors and Scientific Research Publishing Inc.

This work is licensed under the Creative Commons Attribution International License (CC BY).

http://creativecommons.org/licenses/by/4.0/

(c) † Open Access

\section{Abstract}

An in vitro study was conducted to make a comparative study of biochar and biomass on soil bacteria. The responses of three agriculturally important bacteria viz., Bradyrhizobium, Sulphate reducing and Iron oxidizing bacteria, were studied. Total viable counts were also made. Three different types of biomasses viz., rice husk, rice straw and saw dust, and biochars produced thereof were used for the study. The biomasses or biochars were applied to the soil at a rate of $5 \mathrm{t} / \mathrm{ha}$. The study included seven different treatments of biomasses and corresponding biochars including a control. Total counts were made on the original materials as well as on the treated soils at 30,60 and 90 days of incubation. Bacterial count was higher in all the biomass treated soils than the corresponding biochar treated ones including control. Although the presence of Bradyrhizobium, sulphate reducing and iron oxidizing bacteria were not noted in the fresh soils, their presence, however, was noted after incubation periods. The counts of all three bacteria are however lower in the biochar treated soils than the corresponding biomass treated soils. The paper discusses about the microbial soil health vis-à-vis biochar application, indicating that the materials exert negative effect on the soil microbial population and thereby likely to jeopardize soil health and crop production.

\section{Keywords}

Biochar, Bradyrhizobium Incubation, Soil Health

\footnotetext{
${ }^{*}$ Corresponding author.
} 


\section{Introduction}

Soil quality in terms of soil health has gained much concern over the last few years as fertile soil is the best insurance against food insecurity and climate vulnerability. Since soil is a complex biological system, approximately $5 \%$ of soil is occupied by microbes, especially bacteria. For that, soil fertility is determined by the biological factors, mainly by microbes as they are considered the life of soil. Soil microorganisms are crucial in recycling of soil nutrients, decomposing organic matter, fixing essential nutrients, improving soil properties, maintaining soil structure and above all conserving soil quality. These microbes need regular supplies of organic matters in the form of biomass to maintain their survival and growth. About $60 \%$ of the soil carbon is in the form of organic matter which determines much of the soil's quality [1].

Very recently, charred biomass-biochar, came into the context of soil health which is increasingly central to many concerns of the modern society both nationally and internationally. Problems of the global environment, recognition of the need to recycle natural resources and discovery of the high technology in agriculture have placed the biochar in the limelight. Biochar is crucial in reducing waste, producing renewable energy, improving soil properties, reducing green house gases, sequestering soil carbon and combating global climate change [2].

Much is known about the potential advantages of biochar. However, some important knowledge gaps exist about its drawbacks. A big debate exists about the impacts of biochar on soil health. It thus becomes pertinent to explore the response of soil microbes to biochar addition. It is equally important to assess whether biochar is equally good as biomass. Although many research reported positive effects of biochar with respect to soil microbial health yet, in recent times, negative effects of char in relation to soil microorganisms has also been realized [3]. As a part of this approach, viable counts of three agriculturally important bacteria viz., Bradyrhizobium, Sulphate reducing and Iron oxidizing bacteria were enumerated both in the original materials and in the treated soils after various incubation periods. The present research aimed to assess the effects of biochar on soil bacterial abundance and ultimately on overall soil microbial health. This could be linked to determine whether biochar brings the same advantages for soil microbes like the biomass.

\section{Materials and Methods}

\subsection{Sampling Site}

For the soil used in the present investigation, an agriculture field in the village, Jagir Dighulia in Atigram union of Manikganj District, was selected for soil sampling (Figure 1). The geo-reference of the sampling site is $23^{\circ} 51.88 \mathrm{~N}$ and $90^{\circ} 06.219 \mathrm{E}$. The soil belongs to the Melandaha soil series; USDA family code-Loamy, mixed, non acid, hyperthermic; USDA soil taxonomy-Aeric Haplaquepts [4]; FAO (UNESCO legend)-Gleysol (Eutric Gleysol).

\subsection{Collection, Preparation and Processing of Soil Sample}

Soil sample was selected randomly from the agriculture field. The bulk soil sample representing $0-15 \mathrm{~cm}$ depth from surface was collected by the composite sampling method as suggested by the United States Department of Agriculture [5]. The depth was decided to represent the rhizosphere as soil bacteria were to be observed. The soil sample was processed following standard procedure [6].

\subsection{Collection and Processing of Biomass Samples}

Three different types of biomass viz., rice husk, rice straw and saw dust were collected for producing three different types of biochar. Rice husk biomass was collected from a local Rice Mills, rice straw from the local farmers and the saw dust was collected from ad Saw Mill in Dhaka. All biomass samples were oven dried (at low temperature). The straw was cut into small pieces before drying. After oven drying all samples were ground and screened separately through a $0.25 \mathrm{~mm}$ sieve.

\subsection{Production and Processing of Biochar}

A big earthen pot was taken and metal wires were arranged in a criss-cross arrangement over the pot so that it can support the small pots. Individual biomass was placed layer by layer in small earthen pots. These pots were covered with earthen lids. 4 - 5 pots were placed on the wire arrangement in such a way that pots were uniformly 


\section{Location of the Soil Sampling Site}

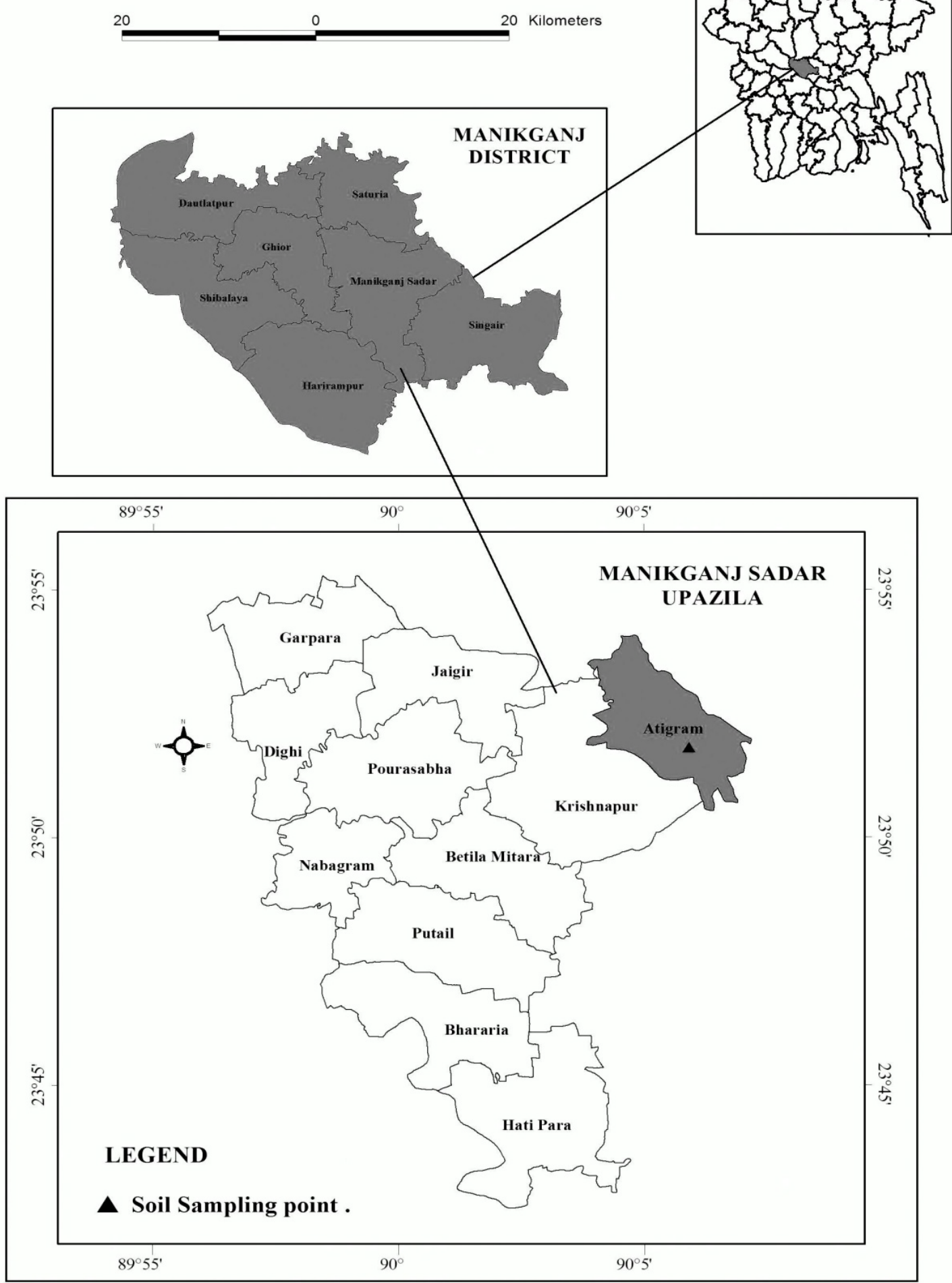

Figure 1. GPS-GIS based location map of the soil sampling site. 
heated from all sides. Finally, fire was lighted and accelerated time to time by adding wood chips and kero- sene oil. After about an hour, when the biomass was turned to biochar, fire was stopped. The lid of the pot was not opened until it cooled down completely. After cooling of the biochar, lids of the pots were opened, screened through $0.25 \mathrm{~mm}$ sieve.

\subsection{Laboratory Analysis}

Various physical, chemical and physico-chemical properties of the soil, biomass and biochar samples were analyzed by the procedures described in [6].

\subsection{Experimental Setup to Observe Changes of Soil Bacteria in Biomass and Biochar}

In order to assess the impact of biomass and biochar on soil bacteria, a pot experiment was carried out in the Department of Soil, Water and Environment, University of Dhaka. Microbiological studies were conducted in the Industrial Microbiological Laboratory, Bangladesh Council of Scientific and Industrial Research (BCSIR). For the incubation study, 21 plastic pots were filled with soil mixed with the biomasses or the biochars. The materials were added to soil at the rate of $5 \mathrm{t} / \mathrm{h}$. There were a set of control pots where no materials were added to the soil. The pots were incubated for three different periods viz., 30, 60 and 90 days. The seven treatments were designated as C (control), BM1 (soil + biomass 1-rice husk), BM2 (soil + biomass 2-rice straw), BM3 (soil + biomass 3-saw dust), BC1 (soil + biochar 1-rice husk), BC2 (soil + biochar 2-straw), BC3 (soil + biochar 3-saw dust). Sterilized distilled water was added to maintain field condition.

\subsection{Microbiological Studies}

At the end of each incubation periods, sample was collected from each pot and viable counts for specific bacteria viz., Bradyrhizobium; iron-oxidizing and sulfur-reducing bacteria were made. Total viable counts were also made. The count was made both before and after addition of treatments to make a comparative study. The experiment was conducted in an aseptic condition which prevented contamination and assured accuracy of result.

\subsubsection{Microbiological Studies}

TVC was enumerated by the number of CFU (Colony Forming Units) with the colony counting technique to measure cells capable of dividing. It was done according to the serial dilution (pour-plate) technique as described by [7]. Samples and $0.85 \% \mathrm{NaCl}$ solution were mixed in 1:10 ratio in Erlenmeyer flask (10 ${ }^{-1}$ dilution). 1 $\mathrm{ml}$ solution was transferred to McCartney bottle $\left(10^{-2}\right)$ which was further diluted up to $10^{-8}$. Each bottle contained $9 \mathrm{ml}$ saline solution. From each of the dilutions, $1 \mathrm{ml}$ solution was placed in the corresponding individual petri-dishes and at the same time, sterilized, hot Plate Count Agar (PCA) was poured onto the dishes. The dishes were rotated clockwise and anticlockwise to ensure proper mixing and then left to solidify. After the media solidified, they were kept in an incubator, upside down, at $37^{\circ} \mathrm{C}$ for 24 hours for the bacteria to grow [8].

Number of colony was counted manually and the CFU was calculated by multiplying the number of colonies with the dilution factor. For each dilution, number of colony on each individual plate was counted and amount of bacteria were calculated by using the following equation as described in [9].

$$
\mathrm{CFU} / \mathrm{g}=(\text { number of colonies } \times \text { dilution factor }) / \text { volume of culture plate }
$$

\subsubsection{Total Viable Counts of Specific Bacteria}

In order to count the Bradyrhizobium, Iron oxidizing and Sulphate reducing bacteria, media specific to these organisms were prepared; and viable count was made by serial dilution technique.

\subsubsection{Bradyrhizobium}

Bradyrhizobium was cultured by YEM (Yeast Extract Mannitol) agar medium as described in [10]. YEM agar contained the following constituents: $\mathrm{K}_{2} \mathrm{HPO}_{4}(0.5 \mathrm{~g} / \mathrm{l}), \mathrm{MgSO}_{4} \cdot 7 \mathrm{H}_{2} \mathrm{O}(0.2 \mathrm{~g} / \mathrm{l}), \mathrm{NaCl}(0.2 \mathrm{~g} / \mathrm{l})$, and $\mathrm{CaCO}_{3}(0.2$ $\mathrm{g} / \mathrm{l}), \mathrm{FeCl}_{3} \cdot 6 \mathrm{H}_{2} \mathrm{O}(0.01 \mathrm{~g} / \mathrm{l})$, mannitol $(10 \mathrm{~g} / \mathrm{l})$, yeast extract $(0.4 \mathrm{~g} / \mathrm{l})$, agar $(15 \mathrm{~g} / \mathrm{l})$. YEM agar was amended with the following constituents: cyclohexamide (200 mg), pentacholoronitrobenzene (100 mg), sodium benzyl penicillin (25 mg), chlonamphenicol (10 mg), neomycine (25 mg), sterilized water (1 litre) and pH (6.8 - 7.0). In- 
itially, soil samples and BPW (Buffered Peptone Water) were taken at a ratio of 1:10 and was subjected to stomacher machine to ensure homogenization of the samples. Following stomaching, serial dilution was done up to $10^{-8}$ and then $1 \mathrm{ml}$ portion of different diluted samples were inoculated into the YEM agar plates. After incubation $\left(37^{\circ} \mathrm{C}\right)$ for 5 days, colonies started to appear as described in [10]. Presence of Bradyrhizobium was confirmed by observing morphological properties and some biochemical activities of colony. Viable count was done manually.

\subsubsection{Sulphate Reducing Bacteria}

Sulphate reducing bacteria was cultured by "Starkey" medium containing the following constituents: $\mathrm{K}_{2} \mathrm{HPO}_{4}$ $(0.50 \mathrm{~g} / \mathrm{l})$, peptic digest of animal tissue $(2 \mathrm{~g} / \mathrm{l})$, beef extract $(1 \mathrm{~g} / \mathrm{l}), \mathrm{Na}_{2} \mathrm{SO}_{4}(1.5 \mathrm{~g} / \mathrm{l}), \mathrm{MgSO}_{4} \cdot 7 \mathrm{H}_{2} \mathrm{O}(2 \mathrm{~g} / \mathrm{l})$, $\mathrm{CaCl}_{2} \cdot 2 \mathrm{H}_{2} \mathrm{O}(0.10 \mathrm{~g} / \mathrm{l}), \mathrm{Fe}\left(\mathrm{SO}_{4}\right)_{2} \mathrm{NH}_{4} \cdot 12 \mathrm{H}_{2} \mathrm{O}(0.392 \mathrm{~g} / \mathrm{l}), \mathrm{C}_{6} \mathrm{H}_{7} \mathrm{NaO}_{6}(0.10 \mathrm{~g} / \mathrm{l}), \mathrm{NaC}_{3} \mathrm{H}_{5} \mathrm{O}_{3}(3.5 \mathrm{~g} / \mathrm{l})$, agar $(7.5 \mathrm{~g} / \mathrm{l})$ and $\mathrm{pH}(7.5 \pm 0.3)$. After incubation of $30^{\circ} \mathrm{C}$ for 2 weeks, colonies began to appear as described in [11]. Sulphate reducing bacteria were cultured and colonies emerged as described above and viable count was done manually.

\subsubsection{Iron Oxidizing Bacteria}

Iron oxidizing bacteria was cultured in a broth medium by mixing $\mathrm{A}$ and $\mathrm{B}$ solutions. Solution $\mathrm{A}$ and $\mathrm{B}$ contained the following constituents: $\mathrm{NH}_{4} \mathrm{SO}_{4}(0.5 \mathrm{~g}), \mathrm{KCl}(1 \mathrm{~g}), \mathrm{Na}_{2} \mathrm{SO}_{4}(1 \mathrm{~g}), \mathrm{MgSO}_{4} \cdot 7 \mathrm{H}_{2} \mathrm{O}(0.1 \mathrm{~g}), \mathrm{K}_{2} \mathrm{HPO}_{4}(2 \mathrm{~g})$, $\mathrm{CaNO}_{3}(5 \mathrm{~g}), \mathrm{H}_{2} \mathrm{O}(700 \mathrm{ml})$; and $\mathrm{FeSO}_{4} \cdot 7 \mathrm{H}_{2} \mathrm{O}(3 \mathrm{~g}), 1 \mathrm{~N} \mathrm{H}_{2} \mathrm{SO}_{4}(10 \mathrm{ml}), \mathrm{H}_{2} \mathrm{O}(290 \mathrm{ml})$, respectively. Then the soil samples were added to the broth at a ratio of $1: 10$ and incubated at $30^{\circ} \mathrm{C}$ for 24 hours in a shaking incubator. Serial dilution was done and diluted samples were inoculated into the agar plates as before. After incubation for 24 hours, colonies began to appear. Gram staining was done to confirm the growth and then viable count was done manually.

\subsubsection{Statistical Analysis}

The experimental data were statically analyzed by using the Microsoft Excel and the MINITAB (version 16). The data obtained were analyzed to find out the analysis of variance resulting from the experimental treatments and days of incubation. Paired $t$-test was done to know whether or not there is a significant difference between the biomass and biochar treatment.

\section{Results and Discussions}

The selected soil, biomasses and biochars were analyzed to determine the nutritional status and the results are presented in Table 1.

\subsection{Total Viable Count (TVC) of the Initial Soil, Biomass \& Biochar}

Bacterial colonies started to appear after 24 hours of incubation in soil and biomass inocula indicating the presence of bacteria in these materials. Initially, the soil and three biomass samples possessed Total Viable Count (TVC) of $60 \times 10^{4}, 50 \times 10^{4}, 70 \times 10^{4}$, and $45 \times 10^{4}$ respectively. Straw biomass (per gramme) (M2) had more viable count even than the soil itself. It could be due to its origin. Conversely, no count was observed in the biochar samples. The reason could be that, high temperature for producing char might have killed the microbes that are present in the corresponding biomass. It has been observed that condensates from the smoke of char contain easily degradable substances with small amounts of inhibitory agents which could be utilized by the microbes [12]. According to DeLuca and Gundale [13], as biochar possesses high C:N ratio (up to 400), it undergoes rapid mineralization of labile carbon leading to reduced soil nitrogen. As a result, availability of total $\mathrm{N}$ and $\mathrm{C}$ decrease for the microbes. These facts could be attributed to the absence of any viable organisms in the biochars.

\subsection{Total Viable Counts (TVC) of the Treated Soils at Different Incubation Periods}

Bacterial growth was higher for all of the biomass treated soils compared to that of the corresponding biochar treated as well as the control soils. Although there was no colony in the biochars initially, when biochars were added to soils, colonies appeared though the number was relatively smaller. Soil microbes could not survive in presence of char due to its antagonistic effects resulting from nutrients deficiency, decreased sorption of enzymes, and increased binding of enzymes. Complex compounds (benzene, phenolic ring) are formed too that are 
not easily degradable by the common microbes. Graber et al. [14] noted that except some resistant microbes, most microbes die in course of time due to char. They also observed that enzyme activity, particularly chitinase, aminopeptidase and phosphatase; was drastically reduced. However, respiration, microbial biomass, population growth and efficiency increased significantly with increasing char concentrations [12].

AVOVA test indicates that the treatment had highly significant effect on total viable count $(\mathrm{P}=0.000)$ while the effects of incubation periods was not significant $(P=0.205)$. Except for the $\mathrm{M} 1$ and $\mathrm{C} 1$ (30 days: $\mathrm{P}=0.06)$ and M2 and C2 (60 days: $\mathrm{P}=0.09$ ), biomasses and biochars had significant differential effect on the TVC.

Following incubation, bacterial growth appeared after 24 hours as before. Total viable counts of different treated soils at the incubation periods of 30, 60 and 90 days are presented in Figure 2.

Table 1. Basic properties of the soil, biomass and biochar samples.

\begin{tabular}{|c|c|c|c|c|c|c|}
\hline \multirow{2}{*}{$\begin{array}{c}\text { Name of Parameters } \\
\text { Textural Class }\end{array}$} & \multicolumn{6}{|c|}{ Parameter Values of the Soil Sample } \\
\hline & Silt Loam & \multicolumn{4}{|c|}{ Organic Matter (\%) } & 0.5 \\
\hline Sand (\%) & 13.9 & \multicolumn{4}{|c|}{ Total Nitrogen (\%) } & 0.03 \\
\hline Silt (\%) & 74.1 & \multicolumn{4}{|c|}{ CEC (me/100g) } & 14.7 \\
\hline Clay (\%) & 12.0 & \multicolumn{4}{|c|}{ Available Nitrogen (ppm) } & 40 \\
\hline Moisture Percentage (\%) & 13.2 & \multicolumn{4}{|c|}{ Available Phosphorus (ppm) } & 5 \\
\hline $\mathrm{pH}$ & 5.6 & \multicolumn{4}{|c|}{$\mathrm{NH}_{4} \mathrm{OAc}$ extractable Potassium (ppm) } & 0.003 \\
\hline Organic Carbon (\%) & 0.3 & \multicolumn{4}{|c|}{$\mathrm{CaH}_{2} \mathrm{PO}_{4}$ extractable Sulphur (ppm) } & 10 \\
\hline C:N Ratio & & \multicolumn{5}{|c|}{$10: 1$} \\
\hline \multirow{2}{*}{ Name of Parameters } & \multicolumn{6}{|c|}{ Parameter Values of the Biomass and Biochar Samples } \\
\hline & BM1 & BM2 & BM3 & BC1 & BC2 & ВC3 \\
\hline Moisture Percentage (\%) & 4.7 & 15.5 & 22.0 & N/A & N/A & N/A \\
\hline $\mathrm{pH}$ & 6.6 & 7.6 & 6.0 & 7.6 & 10.6 & 6.7 \\
\hline Organic Carbon (\%) & 20.7 & 48.2 & 42.2 & 40.9 & 51.9 & 13.8 \\
\hline Organic Matter (\%) & 35.7 & 83.2 & 72.8 & 70.5 & 89.6 & 23.7 \\
\hline CEC (me/100g) & 17.2 & 12.8 & 16.2 & 20.2 & 16.0 & 17.5 \\
\hline Total Nitrogen (\%) & 0.8 & 0.3 & 0.2 & 0.5 & 0.3 & 0.2 \\
\hline Total Phosphorus (\%) & 0.9 & 0.04 & 0.1 & 1.7 & 0.2 & 0.5 \\
\hline Total Potassium (\%) & 0.8 & 0.3 & 0.3 & 0.2 & 0.7 & 0.8 \\
\hline Total Sulphur (\%) & 8.9 & 114.2 & 22.3 & 20.7 & $\mathrm{ND}^{*}$ & $\mathrm{ND}^{*}$ \\
\hline
\end{tabular}

${ }^{*} \mathrm{ND}=$ Not Detected.

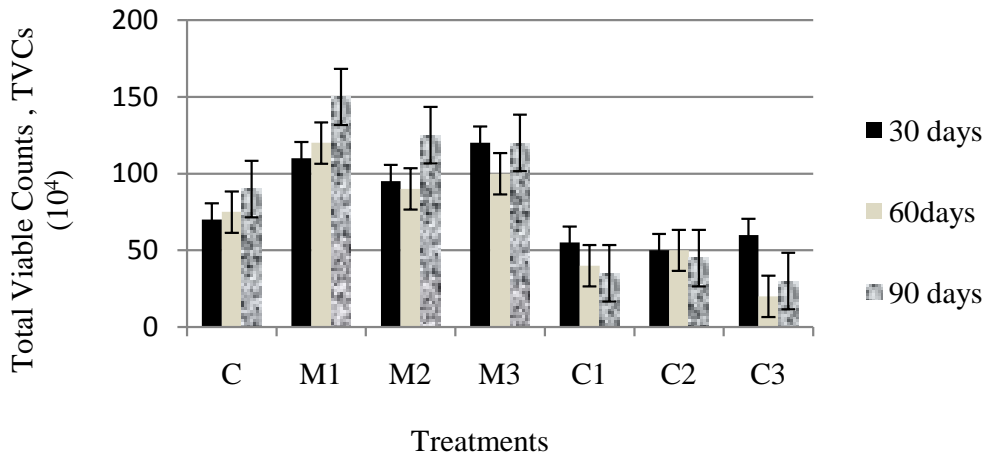

Figure 2. Total viable count at different incubation periods. Treatments and Notations: $\mathrm{C}=$ Control, $\mathrm{M} 1=$ Soil + Rice husk biomass, $\mathrm{M} 2=$ Soil + Straw biomass, M3 = Soil + Saw dust biomass, C1 = Soil + Rice husk biochar, C2 = Soil + Straw biochar, C3 = Soil + Saw dust biochar. 


\subsection{Total Viable Counts of Specific Bacteria}

\subsubsection{Bradyrhizobium}

Although no growth of Bradyrhizobium was observed in soil, biomass and biochar materials before incubation, growth appeared at the end of incubation. After incubation, all soils with biomass treatments showed higher growth than that of corresponding biochar treatments. The bacteria might have remained dormant initially in soil. However, when the soil was brought to field condition, the dormant cells became active. Growth of Bradyrhizobium was not conducive in the laboratory condition. Thus, the incubation periods needs to be lengthened.

Count of Bradyrhizobium decreased in biochar treated soils. The reason might be that Bradyrhizobium are able to use $\mathrm{NH}_{4}^{+}$or $\mathrm{NO}_{3}^{-}$as nitrogen source but when char is added utilization of these compounds is hampered. Extreme $\mathrm{pH}$ hampers nodulation of Bradyrhizobium which leads to reduced growth and population [15]. In the present investigation, it was observed that when biomass was converted to char soil alkalinity increasedsignificantly (Table 1) which might have adversely affected proliferation of the bacteria. Reports are also there that biochar significantly increased biological nitrogen fixation by Rhizobium and improved BNF and biomass productivity [16].

AVOVA test indicates that the treatment had highly significant effect on viable count of Bradyrhizobium $(\mathrm{P}=$ $0.000)$ while the effects of incubation periods $(P=0.017)$ was significant at a lower level. The biomasses and biochars had significant differential effect on the viable count of Bradyrhizobium, except for the M1 and C1 at $30(\mathrm{P}=0.07)$ and $60(\mathrm{P}=0.27)$ days.

Following incubation, colorless to cream colored, homogenous colonies of Bradyrhizobium emerged. Viable counts of treated soils at 30, 60 and 90 days are presented in Figure 3.

\subsubsection{Sulphate Reducing Bacteria}

In all incubation periods, growth was higher in biomass treatments than their corresponding biochar treatments. In case of biochar treatments, bacterial growth was consistently higher than the controls; however, the growth plummeted at 90 days. Sulfur, prerequisite for the Sulphate reducing bacteria as an energy source, might have degraded in presence of chars. When the biomass was converted to char, much of the $\mathrm{S}$ became concentrated. This phenomenon however, could be related to the source. In the present study, the biochar made from rice husk showed an increased concentration of S after charring while the chars made from rice straw and saw dust lost it (Table 1). Sulphate reducing bacteria prefer simple substrates as energy source that might be degraded due to the formation of char [17]. Biochar additions to mineral soils directly or indirectly affect sorption reactions and $\mathrm{S}$ reduction [18], which might have affected the proliferation of Sulphate reducing bacteria. No published data was found on the effects of biochar on Sulphate reducing bacteria at all.

AVOVA test indicated that both the treatments $(\mathrm{P}=0.015)$ and incubation periods $(\mathrm{P}=0.031)$ had significant effects on viable count of Sulphate reducing bacteria. Except for the M3 and C3 at 90 days $(P=0.003)$ of incubation, the treatments of biomasses and biochars had no significant differential effect.

Following incubation, black colonies of Sulphate reducing bacteria appeared. The viable count for this bacterium in the soil was found to be $50 \times 10^{3} \mathrm{CFU} / \mathrm{gm}$. No count was found either in biomass or in biochar. Counts, after the incubation periods, are presented in Figure 4.

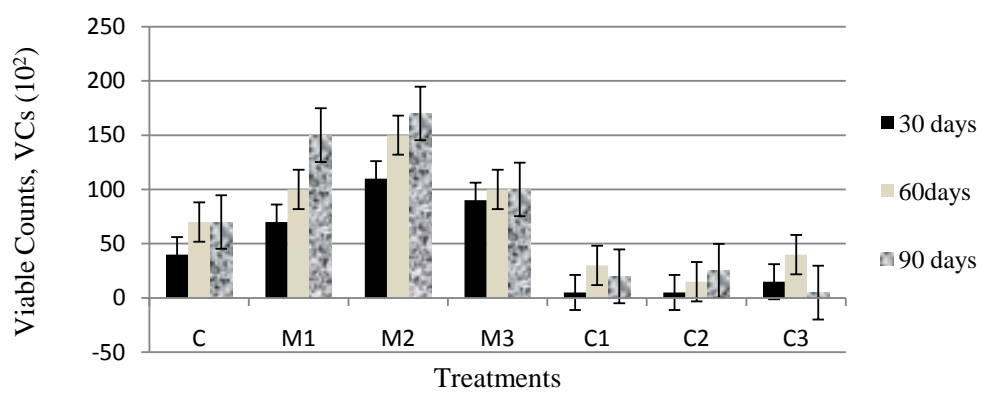

Figure 3. Viable count of Bradyrhizobium at different incubation periods. Treatments and Notations: C = Control, M1 = Soil + Rice husk biomass, M2 = Soil + Straw biomass, M3 = Soil + Saw dust biomass, C1 = Soil + Rice husk biochar, C2 = Soil + Straw biochar, C3 = Soil+ Saw dust biochar. 


\subsubsection{Iron Oxidizing Bacteria}

After incubation periods, all biomass treated soils showed higher viable count than that of the biochar treated soils. No trend was followed between the char treated soils and untreated soils. The count declined in soils with chars up to 60 days but it gradually increased at 90 days. According to Zackrisson et al. [19] and Yu [20], Iron oxidizing bacteria thrive at low oxygen level, near neutral $\mathrm{pH}$, and high $\mathrm{Fe}^{2+}$ levels. Due to biochar addition, these growth factors might be disturbed. However, weak evidence was found that certain iron-oxidizing bacteria are negatively affected by biochar [1].

AVOVA test indicated that both the effects of treatments and incubation period were significant as indicated by $\mathrm{P}=0.001$ and $\mathrm{P}=0.015$ respectively. Except for the M2 and $\mathrm{C} 2$ as well as M3 and C3 at 60 days of incubation $(\mathrm{P}=0.04)$, the biomasses and biochars had no significant differential effect on the viable count.

Viable count of Iron Oxidizing Bacteria was $20 \times 10^{2} \mathrm{CFU} / \mathrm{gm}$ in soil though no colony appeared in biomass and biochar samples. Counts at different incubation periods are presented in Figure 5.

\section{Conclusion}

The present study suggests that biomass serves as the source of energy and nutrition for the soil microbes which provide the substratum for soil health. Though, nowadays, biochar is gaining widespread credibility to address soil quality, it is not as much beneficiary as the biomass. Though produced from biomass, it exerted a negative effect on the abundance and proliferation of soil microorganisms. It might be for relative stability, $\mathrm{pH}$ and physical properties of biochar; general lack of energy; and loss of readily utilizable carbon sources. Source of biochar is also an important factor which needs to be pondered before using it in agricultural soils.

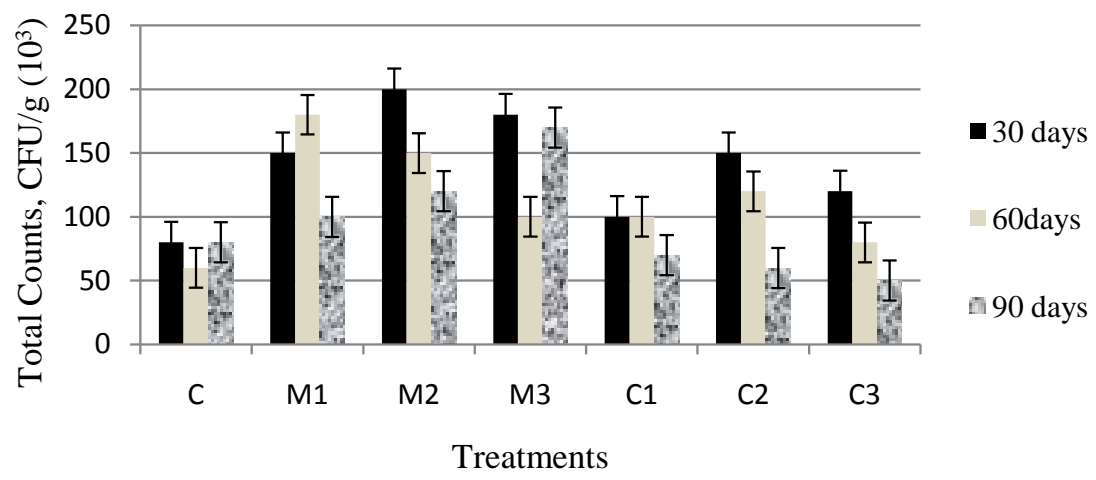

Figure 4. Total viable count (CFU/g) of Sulphate reducing bacteria at different incubation periods. Treatments and Notations: $\mathrm{C}=$ Control, $\mathrm{M} 1=$ Soil + Rice husk biomass, M2 = Soil + Straw biomass, M3 = Soil + Saw dust biomass, C1 = Soil + Rice husk biochar, C2 = Soil + Straw biochar, C3 = Soil + Saw dust biochar.

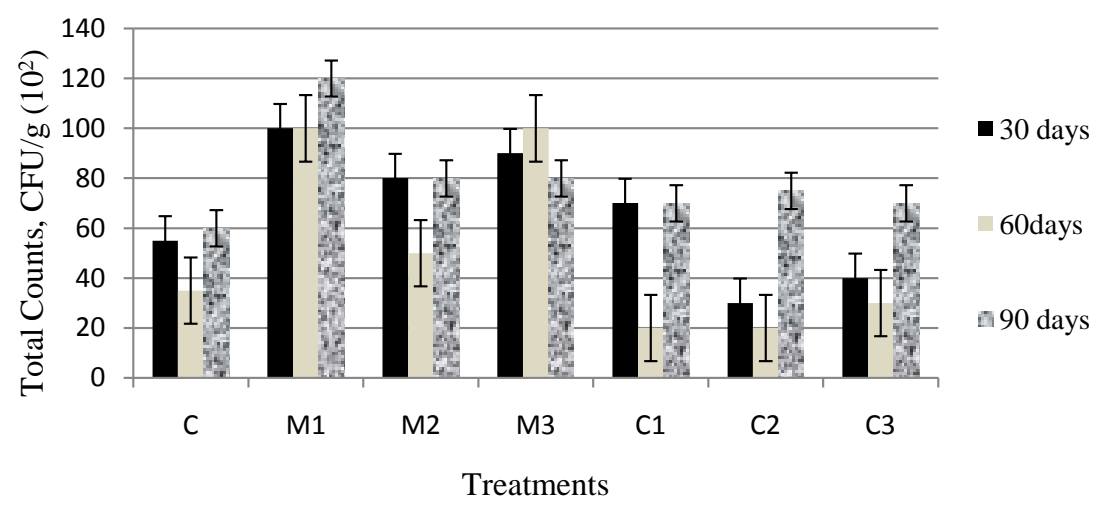

Figure 5. Total viable count (CFU/g) of Iron oxidizing bacteria at different incubation periods. Treatments and Notations: $\mathrm{C}=$ Control, $\mathrm{M} 1$ = Soil + Rice husk biomass, M2 = Soil + Straw biomass, M3 = Soil + Saw dust biomass, C1 = Soil + Rice husk biochar, $\mathrm{C} 2=$ Soil + Straw biochar, $\mathrm{C} 3=$ Soil + Saw dust biochar. 


\section{Acknowledgements}

The authors would like to acknowledge Mr. A. F. M. Manzurul Hoque, Soil Resource Development Institute (SRDI) for his help during soil sample collection. The authors are obliged to the Ministry of Science and Technology, Government of the People's Republic of Bangladesh, for providing financial support for this research.

\section{References}

[1] Ball, P.N., MacKenzie, M.D., DeLuca, T.H. and Holben, W.E. (2010) Wildfire and Charcoal Enhance Nitrification and Ammonium Oxidizing Bacteria Abundance in Dry Montane Forest Soils. Journal of Environmental Quality, 39, 1243-1253. http://dx.doi.org/10.2134/jeq2009.0082

[2] Lehmann, J., Rillig, M.C., Thies, J., Masiello, C.A., Hockaday, W.C. and Crowley, D. (2011) Biochar Effects on Soil Biota-A Review. Soil Biology \& Biochemistry, 43, 1812-1836. http://dx.doi.org/10.1016/j.soilbio.2011.04.022

[3] McElligott, K.M. (2011) Biochar Amendments to Forest Soils: Effects on Soil Properties and Tree Growth. MS Thesis, University of Idaho, Moscow.

[4] Imamul Huq, S.M. and Shoaib, J.U. (2013) The Soils of Bangladesh (e-Book). Springer Dordrecht Heidelberg, New York, London, 165.

[5] United States Department of Agriculture (USDA) (1951) Soil Survey Manual. Handbook 18. Soil Survey Staff, Bureau of Plant Industry, Soils and Agricultural Engineering, United States Department of Agriculture, Washington DC.

[6] Imamul Huq, S.M. and Alam, M.D. (2005) A Handbook on Analyses of Soil, Plant, and Water. University of Dhaka, Dhaka, 43-102.

[7] Cappuccino, J.G. and Sherman, N. (2007) Microbiology: A Laboratory Manual. Dorling Kindersley Pvt. Ltd, License of Pearson Education, New Delhi, India, 143-193.

[8] Benson, H.J. (2002) Microbiological Applications: Laboratory Manual in General Microbiology. 8th Edition, McGraw Hill, New York, 4.

[9] Growth and Enumeration of Viable Cells and Unknown Two. http://www.uiweb.uidaho.edu/micro_biology/250/Week5.pdf

[10] El Sheikh, E.A.E. and Wood, M. (1989) Response of Chickpea and Soybean Rhizobia to Salt: Influence of Carbon Spruce, Temperature and pH. Soil Biology \& Biochemistry, 21, 883-887. http://dx.doi.org/10.1016/0038-0717(89)90076-X

[11] Eaton, A.D., Clesceri, L.S. and Greenberg, A.W. (2005) Standard Methods for the Examination of Water \& Wastewater. 21st Edition, American Public Health Association (APHA), Washington DC.

[12] Steiner, C. (2006) Slash and Char as Alternative to Slash and Burn: Soil Charcoal Amendments Maintain Soil Fertility and Establish a Carbon Sink. Ph.D. Dissertation, University of Bayreuth, Bayreuth, 13-28.

[13] DeLuca, T.H. and Gundale, M.J. (2006) Temperature and Source Material Influence Ecological Attributes of Ponderosa Pine and Douglas-Fir Charcoal. Forest Ecology and Management, 231, 86-93.

[14] Graber, E.R., Harel, Y.M., Kolton, M., Cytryn, E., Silber, A., David, D.R., Tsechansky, L., Borenshtein, M. and Elad, Y. (2010) Biochar Impact on Development and Productivity of Pepper and Tomato Grown in Fertigated Soilless Media. Plant \& Soil, 337, 481-496. http://dx.doi.org/10.1007/s11104-010-0544-6

[15] Mensah, J.K., Esumeh, F., Iyamu, M. and Omoifo, C. (2006) Effects of Different Salt Concentrations and pH on Growth of Rhizobium sp. and a Cowpea-Rhizobium Association. American-Eurasian Journal of Agricultural \& Environmental Science, 1, 198-202.

[16] Rondon, M.A., Lehmann, J., Ramírez, J. and Hurtado, M. (2007) Biological Nitrogen Fixation by Common Beans (Phaseolus vulgaris L.) Increases with Bio-Char Additions. Biology and Fertility of Soils, 43, 699-708. http://dx.doi.org/10.1007/s00374-006-0152-z

[17] Castro, H., Reddy, K.R. and Ogram, A. (2002) Composition and Function of Sulphate-Reducing Prokaryotes in Eutrophic and Pristine Areas of the Florida Everglades. Applied and Environmental Microbiology, 68, 6129-6137. http://dx.doi.org/10.1128/AEM.68.12.6129-6137.2002

[18] DeLuca, T.H., MacKenzie, M.D. and Gundale, M.J. (2009) Biochar Effects on Soil Nutrient Transformations. In: Lehmann, J. and Joseph, S., Eds., Biochar for Environmental Management and Technology, Earthscan, London, 251270.

[19] Zackrisson, O., Nilsson, M.C. and Wardle, D.A. (1996) Key Ecological Function of Charcoal from Wildfire in the Boreal Forest. Oikos, 75, 10-15. http://dx.doi.org/10.2307/3545580

[20] Yu, R. (2007) Iron Oxidizing Bacteria at the Groundwater/Surface Water Interface: Presence, Diversity, Activity and Role in Natural Iron Deposition. University of Connecticut, Storrs. 